\title{
Evaluation of the Employee Core Competencies Influencing the Performance Appraisal System with Reference to Agriculture Research Institutes, Hyderabad: A Multiple Regression Analysis
}

\author{
K. D. V. Prasad ${ }^{*}$, Rajesh Vaidya ${ }^{2}$, M. Mrutyunjaya Rao ${ }^{1}$ \\ ${ }^{1}$ Faculty of Commerce, Rashtrasant Tukdoji Maharaj Nagpur University, Nagpur, India \\ ${ }^{2}$ Department of Management and Technology, Shree Ramdeobaba College of Engineering and Management, Nagpur, India \\ Email: *Prasadkanaka2003@yahoo.co.in
}

How to cite this paper: Prasad, K.D.V., Vaidya, R. and Mrutyunjaya Rao, M. (2016) Evaluation of the Employee Core Competencies Influencing the Performance Appraisal System with Reference to Agriculture Research Institutes, Hyderabad: A Multiple Regression Analysis. Journal of Human Resource and Sustainability Studies, 4, 281 292.

http://dx.doi.org/10.4236/jhrss.2016.44028

Received: September 19, 2016

Accepted: October 18, 2016

Published: October 21, 2016

Copyright $\odot 2016$ by authors and Scientific Research Publishing Inc.

This work is licensed under the Creative Commons Attribution International

License (CC BY 4.0).

http://creativecommons.org/licenses/by/4.0/

c) (i) Open Access

\begin{abstract}
In this research study we reported the results on the employee core competencies influencing the evaluation performance appraisal system using multiple regression analysis with reference to Agriculture Research Institutes employees in Hyderabad Metro, India. The primary data were collected from the performance appraisal forms of 400 employees working in the agriculture research institutes in Hyderabad, India consisting of from 300 men and 100 women employees. The seven independent factors, Job knowledge, Skill level, Job execution, Initiative, Client Orientation, Team Work, Compliance to Policies and Practices, one dependent factor outcome of the Performance Appraisal System (PAS), the Rating were measured. The descriptive analysis, correlation techniques and parametric statistics like t-test and multiple regression analysis were carried out to arrive at the conclusions. To measure the reliability of the scale used for this study, and internal consistencies of the instrument, the reliability statistics-Cronbach's alpha (C-Alpha) was estimated. The overall C-Alpha value is 0.91 , and the C-Alpha values for all the factors ranged from 0.81 to 0.89 , whereas overall Spearman Brown Split-half is measured at 0.88. The multiple regression analysis reveals $74 \%$ variance observed in this model and except client orientation all core-competencies are influencing the model and outcome of the performance appraisal outcome-the Final Rating.
\end{abstract}

\section{Keywords}

Performance Appraisal, Cronbach Alpha, Spearman-Brown Reliability, Effectiveness, Regression 


\section{Introduction}

Performance Appraisal is a formal system of review and evaluation of individual or team task performance, and in general peers review an individual's performance on a continuing yearly basis. The Performance Appraisal System (PAS) is a development tool used to measure the actual performance in an organization, aligning the strategic goals with that of individual performance. Using PAS an employee's performance is measured against core competencies such as job knowledge, Skill level, Job execution, Initiative, Client orientation, Team Work, quality and quantity of output, leadership qualities, and compliance to policies and practices including safety and environment, efficient handling of available resources, intuitiveness to take new assignments. However the core competencies will vary from organization to organizations depending on its objectives, business strategies, and mission.

The performance management is an extensive, methodical, sequential and continuous process that involves performance mapping processes and sequences [1]. Performance measurement is the process that an organization follows to objectively measure how well its stated objectives/mission or goals are being met. In general this involves phases like, articulating and arriving at an agreement on objectives, selecting performance indicators and setting goals/challenges, observing performance, and analyzing those results against a set of goals that were formulated in the organization. Organizations that emphasize accountability tend to use performance targets, but too much emphasis on "hard" targets can potentially have dysfunctional consequences. Organizations focus more on management improvement which may place less emphasis on setting and achieving targets, and instead require organizations to demonstrate steady improvements in performance. In most of the organizations across the globe an employee performance is measured on yearly basis. In general most of the organizations include the performance appraisal system under Performance Management system, where supervisor/subordinate interviews with a standard performance appraisal form with the factors to be appraised or listed in the form [2]. The performance management provides more opportunities for individuals to discuss their work with their managers in an attractive atmosphere [3]. Performance Appraisal system is a continuous process and a natural aspect of management and assess performance by reference to agreed objectives. Performance management gives direction to the employees through guidance from management (Medlin, 2013). The human resources managers believe that PAS is a good tool for performance improvement [4]. The performance appraisal system, if well designed and implemented, can benefit both the employees and the organizations [5]. DeNisis and Pritchard (2006) [6] aver that attitudes toward performance management affect the performance of employees in organisations.

\section{Use of Performance Appraisal System in Agricultural Research Institutes (ARIs)}

The main objective of PAS in ARI is to improve employee and institutes performance. Though the PAS can some dissatisfaction over how the employee as appraised, still it can help to achieve institutes' vision and mission. PAS is one of the human resources valuable functional area which is helpful in correcting the deviations/errors in 
employee performance. At the Institute PAS is effectively used for Human Resource Planning in assessing a list of staff to be promoted, to identify the underperformed employees who need a corrective action. PAS is also a useful tool for succession planning and provides a profile for the institutes strengths and weakness. The PAS evaluations ratings will be used for Recruitment and Selection at the next level. The ratings will provide benchmarks for evaluating internal applicant responses obtained through interviews. The PAS will be used to identify the Training and Development needs of the institute by identifying the employee deficiencies in those core competencies that effect the outcome of the institute. The PAS system is helpful for career planning, compensation program, succession planning and human resources development.

\section{Review of Literature}

Performance appraisal is an unpleasant management practice. With so much controversy in it, appraisal is continually used in the public sector around the world as an instrument to oversee the performance of its personnel [7]. Researchers suggested to have an effective human resource system for organizations the use of an appraisal system which is reliable and accurate for employee assessment and organisational development [8]-[10]. From the results of the factors influencing the Employees' service performance in Ministry of Education in Sultanate of Omani using Factor Analysis suggested that the training and performance appraisal have a significant influence on the employees' Performance [11].

George Ndemo Ochoti et al. (2012) [12] studied the Factors Influencing Employee Performance Appraisal System: A Case of the Ministry of State for Provincial Administration \& Internal Security, Kenya. Performance Appraisal system is a good tool for human resource management and performance improvement [4]. Involving the employees to understand organizational goals, what is expected of them and what they will expect for achieving their performance goal will help in organizational development [13]. PAS should also link individual performance with reward management [14]. Linking performance with reward increases the levels of performances and should be used in both public and private sectors [15]

Feedback is an important factor of PAS and the rates should be given feedback on their competence and overall progress [16]. The 360 degree feedback method can be utilized by organizations as this method combines evaluations from various sources into over all appraisal [17]. Performance ratings are based on rater evaluations which are subject to human judgements and biasedness. Personal factors and prejudices are like to influence ratings [18]. The interpersonal factors are important to the PAS as they influence the outcome of the interactions [19] (Greenberg, 1993). The employee attitude toward the system is strongly linked to satisfaction with the system. The perceptions of fairness of the system are an important aspect that contributes to its effectiveness [20]. Understanding the employee's attitude and behaviour about the PAS in organizations is important as they are key to determine the effectiveness [21]. Zakaria et al. (2012) [22] reported that (HRM practices can develop the performance of an organisation by con- 
tributing to employee satisfaction. The performance appraisal is arguably one of the more critical factor in terms of organisation performance and appears to be an indispensable part of any HRM system when compared among the HR practices studied [23].

Yee and Chen 2009 [24] applied fuzzy set theory in the multi-criteria performance appraisal system and developed a performance appraisal system utilizing the performance appraisal criteria from an Information and Communication Technology based company in Malaysia. This system uses multifactorial evaluation model in assisting high-level management and following a systemic approach for assessing the employee performance.

\section{Objectives and Hypotheses}

The objective of the study is to present the main factors influence the PAS system in the agriculture sector institute employees;

- To identify the core-competencies that influence PAS at the workplace of Agriculture research institutes in Hyderabad, India.

- To identify whether there are any significant mean differences in the above said factors in influencing the PAS.

Research question

1) Does Performance Appraisal System process influence the organizational performance and effectiveness?

2) Does the seven independent core competencies-Job knowledge, Skill level, Job execution, Initiative, Client Orientation, Team Work, Compliance to Policies and Practices one dependent factor outcome of the PAS Rating influence the PAS?

\section{HYPOTHESES}

Based on the identified problem, research question and the objectives the following hypotheses were formed:

$\mathrm{H}_{1}$ : There are significant differences among seven independent core competencies that influence the PAS.

$\mathrm{H}_{2}$ : There are no significant differences among the core competencies that influence the PAS.

\section{Research Methodology}

\subsection{Conceptual Framework}

The proposed framework was adopted based on the past research [12]. The factors under the study have been represented diagrammatically to show the relationship between independent factors and dependent factors (Figure 1).

\subsection{Data Collection}

Sample Size: A sample size of 400 employees selected using simple random sampling without replacement, where each number of the subset has an equal probability of being chosen, and the demography of sample indicated in the Table 1. 


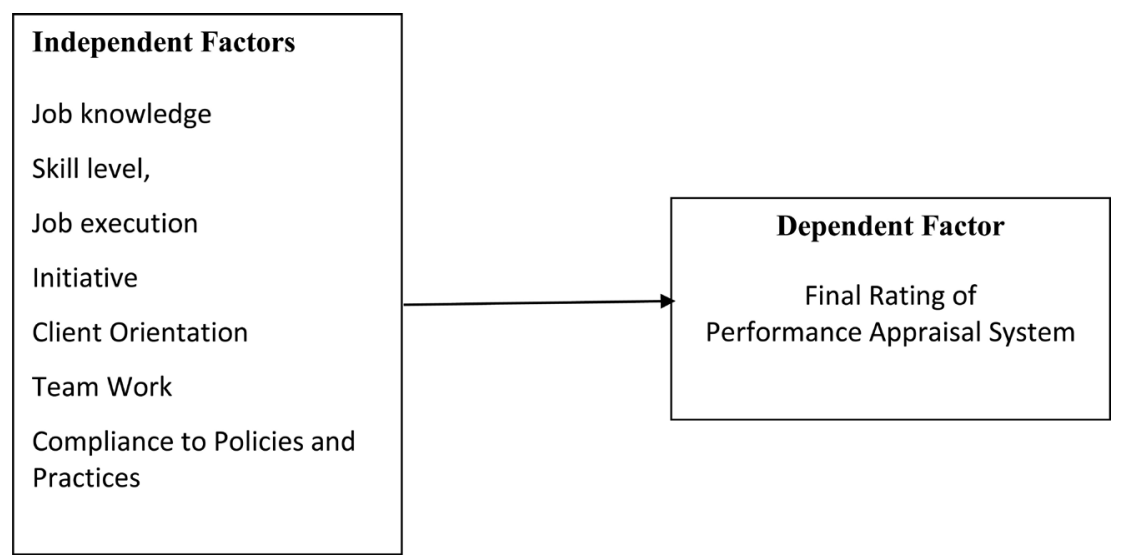

Figure 1. Conceptual framework.

Table 1. Demography of the research sample.

\begin{tabular}{ccc}
\hline Gender & Frequency & Percent \\
\hline Men & 300 & 75 \\
Age: & & \\
$20-29$ & 75 & 25 \\
$30-34$ & 90 & 30 \\
$35-39$ & 66 & 22 \\
$>40$ & 69 & 23 \\
Women & 100 & 25 \\
Age: & & \\
$20-29$ & 25 & 25 \\
$30-34$ & 30 & 30 \\
$35-39$ & 22 & 22 \\
$>40$ & 23 & 23 \\
Total & 400 & 100 \\
\hline
\end{tabular}

Source: Primary data.

\subsection{Research Instrument}

The research instrument used for the study is a standardized, structured undisguised performance appraisal form-a main source for the primary data collection. Secondary data was collected from other sources like published books, websites and records pertaining to the topic. The instrument was divided into 2 sections. In the Section 1, background information/personal such as employee name, designation, institute, program, date of joining and other details of the employee were readily available (pre-filled). The Section 2 of the instrument, the appraisal section where seven core competencies-the factors Job knowledge, Skill level, Job execution, Initiative, Client Orientation, Team Work, Compliance to Policies and Practices one dependent factor outcome of the Performance Appraisal System (PAS) the Rating was used to find out the PAS performance levels of the employees and impact of the PAS. 


\subsection{Data Analysis}

\subsubsection{Methods of Data Analysis}

In our research study we used statistical techniques to analyse the data for drawing inductive inferences from our research data. The descriptive statistics used to summarise the data, and to investigate the survey questionnaire, formulating the hypotheses and the inferential statistics were employed. To measure the central tendency such as means, variance and standard deviation, we used the dispersion methods.

\subsubsection{Reliability Test of the Instrument}

To measure the internal consistency, reliability of our research instrument, and to maintain similar and consistent results for different items with the same research instrument, we used the reliability methods Cronbach's alpha. The Cronbach alpha is an index of reliability that may be thought of as the mean of all possible split-half co-efficient corrected by Spearman-Brown formula [25] and subsequently elaborated by others [26] [27]. The estimated values of the Cronbach's alpha are indicated in Table 2. The Statistical Analytical System (SAS) was used to measure the central tendency, measures of variability, reliability statistics, correlations, parametric tests and to predict the dependent factor PMS based on independent factors multiple regression analysis carried out [28].

Formula for Cronbach's Alpha (|C-alpha can vary between 0.00 and 1.00)

$$
r_{a}\left(\frac{N}{N-1}\right)\left(1-\frac{\Sigma \sigma_{j}^{2}}{\sigma^{2}}\right)
$$

where $r_{a}$ is coefficient alpha; $N$ is the no of items; $\sigma^{2}$ variance of items; $\Sigma \sigma_{j}^{2}$ sum of variances of all items and $\sigma_{j}^{2}$ is the variance of the total test scores.

Table 2. Cronbach's alpha values for factors used in this study.

\begin{tabular}{ccc}
\hline Sl. No & Factor & Cronbach's alpha \\
\hline & Overall & 0.91 \\
2 & Job knowledge & 0.81 \\
3 & Skill level & 0.84 \\
4 & Job Execution & 0.89 \\
5 & Initiative & 0.81 \\
6 & Client Orientation & 0.83 \\
7 & Cooperation and ability to work in teams & 0.83 \\
8 & Compliance to policies and practices including safety & \\
& and environment & 0.81 \\
\hline
\end{tabular}

Overall: Spearman-Brown Split-half statistic: 0.88; Spearman-Brown Prophecy: 0.90. 
The outcome of the PAS Rating was measured using a Likert-type scale with items 1 5 was used (where $1=$ Unsatisfactory, $2=$ Satisfactory, $3=$ Good, $4=$ Excellent and $5=$ Outstanding) in this study. The reliability statistic Cronbach's alpha coefficient value (C-alpha) was calculated to test the internal consistency of the instrument, by determining how all items in the instrument related to the total instrument [29]. This instrument was tested with the data of 50 employees and using SAS the Cronbach alpha static was measured at 0.78 , suggesting a strong internal consistency. Three months later, keying data for all the 400 employees the overall C-alpha measured at 0.89 and it ranged from 0.80 to 0.88 for the 7 independent and 1 independent factors.

The second reliability method Split-half reliability in which scores from the two halves of a test (e.g. even items versus odd items) are correlated with one another and the correlation is then adjusted for test length. The Spearman-Brown's formula is employed enabling correlation as if each part were full length the value is measured 0.88 using formula and the Spearman Brown Prophecy was measured at 0.90.

$R=(2 r h h) /(1+r h h)$ where $r h h$ is the correlation between two halves.

\section{Results}

\subsection{Results from Descriptive Analysis}

The general objective of this research was to assess the independent variables Job Knowledge, Skill Level, Job Execution, Initiative, Team Work, Client Orientation and Compliance to Policies effect on dependent variable final Rating, the data gathered from the performance appraisal forms of the employees was analysed. The calculated Mean, Standard Deviation and Standard Error Values for men and women, for the primary data collected from the respondents $(n=300$, men and $n=100$, women) are presented in the Table 3. The estimate overall SE of 0.04 is relatively small, indicating that the means are relatively close to the true mean of the overall population.

Table 3. Mean, standard deviation and standard error of mean of the primary data of independent and dependent factors.

\begin{tabular}{ccccc}
\hline Sl. No & Factor & Mean & SD & SE \\
\hline 1 & Job knowledge & 3.99 & 0.77 & 0.04 \\
2 & Skill level & 3.90 & 0.80 & 0.04 \\
3 & Job execution & 4.00 & 0.78 & 0.04 \\
4 & Initiative & 3.80 & 0.85 & 0.04 \\
5 & Client orientation & 3.75 & 0.83 & 0.04 \\
6 & Cooperation and ability to work in teams & 4.04 & 0.80 & 0.040 \\
7 & Compliance to policies and practices including safety & 3.97 & 0.77 & 0.08 \\
& and environment & & \\
& Final rating & 3.93 & 0.78 & 0.04 \\
\hline
\end{tabular}


Table 4. Correlation among the study variables.

\begin{tabular}{|c|c|c|c|c|c|c|c|c|}
\hline & Job Knowledge & Job Skill & Job Execution & Initiative & Client Orientation & Tem Work & Compliance To Policies & Rating (Final) \\
\hline Job Skill & $0.691^{* *}$ & 1 & & & & & & \\
\hline Job Execution & $0.539^{* *}$ & $0.511^{* *}$ & 1 & & & & & \\
\hline Initiative & $0.589^{* *}$ & $0.506^{* *}$ & $0.651^{* *}$ & 1 & & & & \\
\hline Team Work & $0.392^{\star *}$ & $0.400^{* *}$ & $0.521^{* *}$ & $0.494^{\star \star}$ & $0.556^{\star *}$ & 1 & & \\
\hline Compliance to Policies & $0.452^{* *}$ & $0.430^{* *}$ & $0.548^{* *}$ & $0.502^{* *}$ & $0.504^{\star *}$ & $0.525^{* *}$ & 1 & \\
\hline Rating (Final) & $0.638^{* *}$ & $0.660^{\star *}$ & $0.735^{\star *}$ & $0.670^{\star *}$ & $0.606^{* *}$ & $0.610^{* *}$ & $0.646^{* *}$ & 1 \\
\hline
\end{tabular}

Pearson Correlation ${ }^{\star *}$ Correlation is significant at prob. $<0.01$; Source: Primary Data.

\subsection{Results from Correlation studies}

The correlation analysis was carried out to measure the relationships between the variables (Table 4 ). All the seven core competencies positively correlated with the rating $(\mathrm{r}=0.66,0.73,0.67,0.60,0.64$, two-tailed, $\mathrm{p}<0.01)$. Overall the correlations are medium and with the available data we cannot conclude the nature of differences among the variables.

\subsection{Results from the Multiple Regression Analysis}

We carried out the multiple regression analysis to predict the value of a dependent variable outcome, Performance based on the value of six independent variables, and to measure the cause and effect relationship between independent and dependent variables (Table 5). With the p-value of zero to four decimal places, the model is statistically significant. The R-squared is 0.739 , meaning that approximately $74 \%$ pf the variability of performance is accompanied for by the variables in the model and in this case $74 \%$ of the variability of performance is accounted for by the model, even after taking into account the number of predictor variables in the model.

From the ANOVA Table it was observed that there are statistically significant differences in group means. With the p-value of zero to four decimal places, the model is statistically significant. The R-squared is 0.739 , meaning that approximately $74 \%$ of the variability of the outcome Final Rating is accompanied for by the variables in the model and in this case $74 \%$ of the variability in Final Rating is accounted for by the model, even after taking into account the number of predictor variables in the model (Table $6)$.

From the Table 7 we can observe that except the independent variable Client orientation all other variables Job Knowledge, Job Skill, Job Execution, Initiative, Team Work and Compliance to Policies are significantly contributing to the Outcome of the model Final Rating. The coefficients of each variable indicates the amount of change one could expect in Final Rating given a one-unit change in the value of that variable, given that all other variables in the model are held constant. If we consider the core 
Table 5. Multiple regression analysis ( $\mathrm{R}$ square data).

\begin{tabular}{ccccc}
\hline Model & $\mathrm{R}$ & R Square & Adjusted R Square & SE of the Estimate \\
\hline 1 & $0.0860^{\mathrm{a}}$ & 0.739 & 0.734 & 0.469 \\
\hline
\end{tabular}

a. Predictors: (Constant), Policies, Job Skill, Team Work, Initiative, Client Orientation, Job Execution, Job Knowledge.

Table 6. Multiple regression analysis (analysis of variance-ANOVA ${ }^{\mathrm{a}}$ ).

\begin{tabular}{cccccc}
\hline Model & Sum of Squares & df & Mean Square & F & Sig. $^{\text {b }}$ \\
\hline Regression & 214.066 & 7 & 30.581 & 158.391 & $0.000^{\mathrm{b}}$ \\
Residual & 75.684 & 392 & 0.193 & & \\
Total & 289.750 & 399 & & & \\
\hline
\end{tabular}

a. Dependent Variable: Rating.

b. Predictors: (Constant), Policies, Job Skill, Team Work, Initiative, Client Orientation, Job Execution, Job Knowledge.

Table 7. Results from regression analysis (Coefficients $\left.{ }^{a}\right)$.

\begin{tabular}{|c|c|c|c|c|c|c|c|}
\hline \multirow{2}{*}{ Model } & \multicolumn{2}{|c|}{$\begin{array}{l}\text { Unstandardized } \\
\text { Coefficients }\end{array}$} & \multirow{2}{*}{$\begin{array}{c}\text { Standardized } \\
\text { Coefficients } \\
\text { Beta }\end{array}$} & \multirow{2}{*}{$\mathrm{t}$} & \multirow{2}{*}{ Sig. } & \multicolumn{2}{|c|}{$\begin{array}{c}95.0 \% \text { Confidence } \\
\text { Interval for B }\end{array}$} \\
\hline & B & Std. Error & & & & $\begin{array}{l}\text { Lower } \\
\text { Bound }\end{array}$ & $\begin{array}{l}\text { Upper } \\
\text { Bound }\end{array}$ \\
\hline & -0.515 & 0.137 & & -3.764 & 0.000 & -0.784 & -0.246 \\
\hline Job Knowledge & 0.096 & 0.041 & 0.093 & 2.344 & 0.020 & 0.015 & 0.176 \\
\hline Job Skill & 0.235 & 0.037 & 0.235 & 6.275 & 0.000 & 0.161 & 0.308 \\
\hline Job Execution & 0.290 & 0.038 & 0.291 & 7.567 & 0.000 & 0.215 & 0.366 \\
\hline Initiative & 0.127 & 0.037 & 0.132 & 3.485 & 0.001 & 0.055 & 0.199 \\
\hline Client Orientation & -0.005 & 0.037 & -0.005 & -0.145 & 0.885 & -0.078 & 0.067 \\
\hline Team Work & 0.165 & 0.034 & 0.165 & 4.860 & 0.000 & 0.098 & 0.232 \\
\hline Compliances to Policies & 0.204 & 0.036 & 0.193 & 5.735 & 0.000 & 0.134 & 0.274 \\
\hline
\end{tabular}

a. Dependent Variable: Rating.

competent independent variable Job Skill, we would expect an increase of 0.235 in the Final Rating score for every one unit increase, in Job Skill assuming that all other variables in the model are held constant. To compare the strength among the coefficients the standardized beta coefficient values computed (Table 7). The Job Execution has highest standardized $\beta$ value (0.291) whereas Client-orientation is lowest $(B=0.005)$. Considering the beta value of Job Execution, one standard deviation increase in Motivation leads to 0.2961 standard deviation increase in predicted final rating, with the other variables held constant. In the same way one standard deviation decrease in the client orientation in the absence of proper client orientation, leads to 0.005 standard deviation decrease in final rating with other variables in the model held constant, and so on. From the values of the estimated regression coefficients the sample regression equation can be written as: 
Table 8. Parameter estimates from the regression analysis: overall appraisal vs final rating.

\begin{tabular}{ccccccc}
\hline Factor & Label & $\begin{array}{c}\text { Parameter } \\
\text { Estimate }\end{array}$ & Standard Error & T value & $\operatorname{Pr}>|t|$ & Standardized Estimate \\
\hline Rating & Constant & -0.444 & 0.138 & -3.215 & $<0.0001$ & 0 \\
Overall & PAS & 1.105 & 0.035 & 31.710 & $<0.0001$ & 0.846 \\
\hline \multicolumn{7}{c}{$Y=-0.515+0.096_{\text {Job Knowledge }}+0.235_{\text {Job Skill }}-0.290_{\text {Job Execution }}+0.127_{\text {Initiative }}$} \\
\multicolumn{7}{c}{$-0.005_{\text {Client Orientation }}+0.165_{\text {Teamwork }}+0.204_{\text {Complianceto Policies }}$}
\end{tabular}

The multiple regression analysis also carried out on overall Performance Appraisal system and its effect on overall Rating and the results are presented in Table 8 . The parameter estimates from the regression analysis and from the standardized beta value 0.846 indicates that an overall increase one standard deviation independent factors of 0.846 standard deviation increase in final rating, indicating a positive impact of employee performance.

Therefore based on the results we reject the $\mathrm{H}_{1}$ : There are significant differences among seven independent core competencies that influence the PAS and accept $\mathbf{H}_{2}$ : There are significant differences among the core competencies that influence the PAS.

\section{Discussion and Conclusions}

The main reason for conducting this study is that authors have not been able to find sufficient literature on evaluating PAS using multiple regression analysis for agricultural research sector. We made an attempt to assess the PAS using multiple regression model including sufficient information address, an overall evaluation of the model, statistical test of individual core competencies and assessment of standardized beta values for the core competencies of the performance appraisal system, and its influence on PAS. This model adequacy is justified by multiple indicators, including an overall test of all parameters, the statistical significance of each predictor, etc. We have carried out the reliability tests for all the dependent and independent factors and the reliability statistics C-alpha, Split-Half reliability and Spearman Prophecy, suggesting the internal consistency of the instrument of the performance appraisal form.

The results of this study are in line with the studies conducted by the several authors using multiple regression analysis [12] [30] [31]. The major limitation of the study is Rating biasedness by the evaluator/peer. The authors have no idea whether the oneto-one interview has been happened when appraising the employee. We recommend this type of studies appraising separately for gender-related parity. The authors recommend that the employee performance appraisal should be not the silver bullet to measure the outcome of the appraisal. Some jobs are easy as the decisions are already programmed to carry; some jobs involve carrying out the non-programmed decisions; and the success of the job depends on the acumen and experience of the employee who is carrying out the job. The authors suggest that while appraising an employee the peer/ supervisor should consider the intricacies and complexities involved in the assignment/ job. 


\section{References}

[1] Garvin, D.A. (1998) The Process of Organizing and Management. http://sloanreview.mit.edu/article/the-processes-of-organization-and-management/.

[2] Dargham, N.A.S. (2009) Effective Management of the Performance Appraisal Process in Lebanon: An Exploratory Study. Maître de Conférences à la FGM.

[3] Armstrong, M. (1991) A Handbook of Personnel Management Practice. 4th Edition, Kogan Page, London.

[4] Longenecker, C.O. and Goff, S.J. (1992) Performance Appraisal Effectiveness: A Matter of Perspective. Advanced Management Journal, 57, 18-23.

[5] Coens, A.T. and Jenkins, M. (2000) Abolishing Performance Appraisals. Berret-Koehler Publishers, Inc., San Francisco.

[6] DeNisi, A. and Protchard, R. (2006) Performance Appraisal, Performance Management and Improving Individual Performance: A Motivational Framework. Management and Organization Review, 2, 253-277. http://dx.doi.org/10.1111/j.1740-8784.2006.00042.x

[7] Vallance, S. (1999) Performance Appraisal in Singapore, Thailand and the Philippines: A Cultural Perspective. Australian Journal of Public Administration, 58, 78-95. http://dx.doi.org/10.1111/1467-8500.00129

[8] Armstrong, M. (2003) A Handbook of Human Resource Management Practice. Kogan Page, London.

[9] Bohlander, G. and Snell, S. (2004) Managing Human Resources. SouthWestern, Mason, Ohio.

[10] Desler, G. (2008) Human Resource Management. 11th Edition, Pearson, Upper Saddle River, New Jersey.

[11] Saleh, A.L.S., Piaw, C.Y. and Idris, A.R. (2015) Factors Influencing the Employees' Service Performance in Ministry of Education n Sultanate of Oman. Procedia Social and Behavioral Sciences, 197, 23-30. http://dx.doi.org/10.1016/j.sbspro.2015.07.043

[12] Ochoti, G.N., Maronga, E., Muathe, S., Nyabwanga, R.N. and Ronoh, P.K. (2012) Factors Influencing Employee Performance Appraisal System: A Case of the Ministry of State for Provincial Administration \& Internal Security, Kenya. International Journal of Business and Social Science, 3, 37-45.

[13] Bertone, S., Brown, M., Cressey, P., Frizzell, J., Keating, C., Morris, A. and Worland, D. (1998) Developing Effective Consultation Practices: Case Studies of Consultation at Work: Melbourne. South Pacific Publishing, Melbourne, Australia.

[14] Townley, B. (1999) Practical Reason and Performance Appraisal. Journal of Management Studies, 36, 287-306. http://dx.doi.org/10.1111/1467-6486.00137

[15] Armstrong M. and Brown, D. (2005) Reward Strategies and Trends in the United Kingdom: the Land of Diverse and Pragmatic Dreams. Compensations and Benefits Review, 37, 41-53. http://dx.doi.org/10.1177/0886368705277659

[16] Longenecker, C.O. (1997) Why Managerial Performance Appraisals Are Ineffective: Causes and Lessons. Journal of Career Development International, 2, 212-218.

http://dx.doi.org/10.1108/13620439710174606

[17] Garavan, T.N., Morley, M. and Flynn, M. (1997) 360-Degree Feedback: Its Role in Employee Development. Journal of Management Development, 16, 134-147. http://dx.doi.org/10.1108/02621719710164300

[18] Cleveland, J.N. and Murphy, K.R. (1992) Analyzing Performance Appraisal as a Goal Directed Behavior. Research in Personnel and Human Resources Management, 10, 121-185. 
[19] Greenberg, J. (1993) The Social Side of Fairness: Interpersonal and Informational Classes of Organizational Justice. In: Cropanzano, R., Ed., Justice in the Workplace: Approaching Fairness in Human Resource Management, Lawrence Erlbaum, Hillsdale, 79103.

[20] Boswell, W.R. and Boudreau, J.W. (2000) Employee Satisfaction with Performance Appraisals and Appraisers. Human Resource Development Quarterly, 11, 283-299.

http://dx.doi.org/10.1002/1532-1096(200023)11:3<283::AID-HRDQ6>3.0.CO;2-3

[21] McDowall, A. and Fletcher, C. (2004) Employee Development: An Organizational Justice Perspective. Journal of Personnel Review, 33, 8-29.

[22] Zakaria, N., Zainal, S., and Nasurdin, A. (2012) Investigating the Role of Human Resource Management Practices on the Performance of SME: A Conceptual Framework. Journal of Global Management, 3, 74-92. http://dx.doi.org/10.1108/00483480410510606

[23] Shrivastava, A. and Purang, P. (2011) Employee Perceptions of Performance Appraisals: A Comparative Study on Indian Banks. The International Journal of Human Resource Management, 22, 632-647. http://dx.doi.org/10.1080/09585192.2011.543639

[24] Yee, C.C. and Chen, Y.Y. (2009) Performance Appraisal System Using Multifactorial Evaluation Model. World Academy of Science, Engineering and Technology, International Journal of Mathematical, Computational, Physical, Electrical and Computer Engineering, 3, 304-308.

[25] Cronbach, L. (1951) Coefficient Alpha and Internal Structure of Tests. Psychometrika, 16, 297-334. http://dx.doi.org/10.1007/BF02310555

[26] Novick, M.R. and Lewis, C. (1975) Coefficient Alpha and the Reliability of Composite Measurements. Psychometrika, 32, 1-13. http://dx.doi.org/10.1007/BF02289400

[27] Kaiser, H.F. and Michael, W.B. (1974) Domain Validity and Generalisability. Educational and Psychological Measurement, 35, 1-13.

[28] SAS Institute Inc. (2008) SAS/STAT ${ }^{\circledR} 9.3$ User’s Guide. SAS Institute Inc., Cary.

[29] Gay, L.R., Mills, G.E. and Airasin, P. (2009) Educational Research: Competencies for Analysis and Applications. Merrill Greenwood, Columbus.

[30] Poornima, V. and John Manohar, S. (2015) Performance Appraisal System and Employee Satisfaction among Its Employees in Bangalore. International Journal of Science and Research, 4, 1169-1174.

[31] Chee Hong, E.N., Zheng Hao, L., Ramesh, K., Ramendran, C. and Vimala, K. (2012) An Effectiveness of Human Resource Management Practices on Employee Retention in Institute of Higher Learning: A Regression Analysis. International Journal of Business Research and Management, 3, 60-79. 
Submit or recommend next manuscript to SCIRP and we will provide best service for you:

Accepting pre-submission inquiries through Email, Facebook, LinkedIn, Twitter, etc.

A wide selection of journals (inclusive of 9 subjects, more than 200 journals)

Providing 24-hour high-quality service

User-friendly online submission system

Fair and swift peer-review system

Efficient typesetting and proofreading procedure

Display of the result of downloads and visits, as well as the number of cited articles

Maximum dissemination of your research work

Submit your manuscript at: http://papersubmission.scirp.org/

Or contact jhrss@scirp.org 